$\begin{array}{lll}\text { ENGINEERING AND } & \text { Vol 1 (1): Pages 1-8 (2020) } \\ \text { DOI 10.37357/1068/ietr. 1.1.01 } & \text { ISSN 2435-7278 } \\ \text { TECHNOLOGY } & \text { D check for updates } \\ \text { REVOLUTION } & \end{array}$

\title{
Performance evaluation of different photovoltaic (PV) modules: A case study
}

Khalil Mohammadi ${ }^{1}$, Najib Rahman Sabory ${ }^{1}$, Kambiz Karimi ${ }^{1}$, Mikaeel Ahmadi ${ }^{2}$, Mir Sayed Shah Danish ${ }^{1,3}$ and Tomonobu Senjyu ${ }^{2}$

${ }^{1}$ Department of Energy Engineering, Faculty of Engineering, Kabul University, Kabul, Afghanistan

${ }^{2}$ Department of Electrical and Electronics Engineering, Faculty of Engineering, University of the Ryukyus, Okinawa, Japan

${ }^{3}$ Strategic Research Projects Center, University of the Ryukyus, Okinawa, Japan

\section{Special Issue Article Open Access Published}

Keywords

- Photovoltaic (PV)

- Solar module

- PV system

- Solar energy

- Sustainable Development

- Stand alone PV

- PV parameters

\section{ABSTRACT}

Climate change and global warmings are the main challenges for today and the future nations from the health and environment perspectives. Energy generation utilizing fossil fuel is the leading cause of these issues. On its opposite side, elimination or suppression of fossil fuel utilization by introducing clean and abundant renewable energy resources could be the best solution. In general, renewable energies have low efficiency and high capital cost compared to conventional fossil fuel-based energy supply. Therefore, without considering proper approaches and techniques, it is not encouraging to supply energy through renewable energy resources. Conquering the problem, we need to find the best method and ways to create cheap and efficient energy by renewable sources as possible. In this paper, a methodology is investigated and proposed to simultaneously save energy and cost considering useful parameters such as the effect of different modules, temperature, location, and tilt angle. An estimation-based tool developed by National Renewable Energy Laboratory (NREL) known as PV Watts, which is utilized in this paper. A $10 \mathrm{~kW}$ photovoltaic system with three different modules in two different locations Kabul and Kandahar in Afghanistan is selected as a case study. From the results, it is found that selection of a specific module for a specific region with different temperatures and appropriate title angles has a significant effect on the performance of photovoltaic systems. It is worthy of mention that before implementing a photovoltaic system, different aspects of the system should be evaluated using proper software/tools in order to achieve optimal energy performance. Finally, better energy system performance contributes to the attraction of investment in renewable energy resources as a clean and sustainable energy supply option.

Received: January 17, 2020; Revised: March 15, 2020; Accepted: March 20, 2020; Published: June 05, 2020

\section{Introduction}

In recent years, photovoltaic systems have been studied from different perspectives due to its a number of attractive technical (easiness in installation, operation, and maintenance), financial (scalable based on energy demand), configuration (stand-alone and grid-connected) features, and deployment flexibilities (in different size for various applications: residential, agriculture, rural, remote, etc.) [1-5]. Therefore the photovoltaic technologies have been developed rapidly than fossil fuels these days because it seems to be the solution for the future and provides sustainable energy.

Global greenhouse gas emissions and renewable energy resources are in the vertex of the worldwide trends, and it is demanded to provide cheap, sustainable, and ecofriendly energy [6]. Energy from sunshine in terms of direct photovoltaic and concentrating solar power is getting more and more involved as power supply shareholders in communities. Photovoltaic technologies application become more viable and accessible due to solving electricity shortages in rural areas. There are many challenges for using photovoltaic systems such as more initial cost and less economic, operation, and margin of safety efficiencies [7]. However, reports indicate a significant $60 \%$ drop in renewable energy technologies cost since 2011, still photovoltaics systems do not compete with fossil fuel-based generation in large scales [8]. Since photovoltaic made several decades ago, there is much effort to conquer these challenges and provide optimal and efficient photovoltaic modules or systems harvesting more energy in less money and less land. In this research, we want to get the optimal photovoltaic system by searching and understanding different issues that affect the cost and efficiency of photovoltaic systems.

A change in power system circumstance is revealed by incorporating intermittent renewable energy resources such as solar and wind power. The planning and operation of a grid power has changed in which more attracts the attention of utility managers towards smart and optimum practices in engineering [9]. The photovoltaic system as one of the important ways for clean energy generation and solution for reducing carbon emission and thus a positive impact on climate change does not have a significant performance to cover the energy demand of a country or a city. However, it can have an essential role in the reduction of dependency to fossil fuel. So, we should seek to find ways or methods to convert the energy of the sun to the 
electricity as efficiently as possible. For this, we need to find the factors which affect the performance of photovoltaic systems. Research interest in the integration of renewable energy into power system has risen significantly among researchers. As the renewable energy technology is investigated to be more reliable and economically feasible, a trend has been made to interconnect renewable energy resources into the existing power system, offering more practicability to end-users, such as [10]:

- reliability improvement and access to electricity;

- peak load shaving;

- selling electricity back to utilities or other consumers;

- power quality improvement

To achieve the highest contribution of renewable energy resources specifically solar power in this research, several technical factors should be investigated and explored. Performance of a photovoltaic system is affected by different factors [11], which is interest of current study to be analyzed. Among different factors, here four-factors are considered to be discussed which have significant impact on the energy output of photovoltaic systems. These factors are different modules which we used for our system, effect of temperature, different location with the different weather condition, and optimum tilt angle for our photovoltaic system. This research covers general ideas about increasing performance and decreasing the cost of photovoltaic systems as well as exploring an optimal module to be used in a specific area.

\section{Problem statement}

There are many issues once considering a photovoltaic system as a sustainable energy resource such as; less efficiency of modules, effect of temperature, dependency on the location (irradiance), and required optimal tilt angle. Different technologies and methods used to build efficient photovoltaic cells and modules. For example, there are using multi-junction tandem cells semiconductors like Gallium Arsenide and Gallium Indium Phosphide to achieve more than $30 \%$ efficiency. However, Its efficiency is acceptable, but is costly and not suitable for use in the largescale photovoltaic system. Alternatively, there is singlecrystalline silicon with more than $20 \%$ efficiency. It has the second most share of the photovoltaic market, and its cost is appropriate for small and large scale of a photovoltaic system. Furthermore, there are technologies like polycrystalline and amorphous thin-film than its efficiency is between $11.5 \%$ to $19.5 \%$ [12]. The polycrystalline technology has the largest share of the photovoltaic market because its cost and efficiency are suitable [13].

Also, some photovoltaic module's parameters like open-circuit voltage, short circuit current, maximum output power, and fill factor affected by temperature [14]. For example, open-circuit voltage, maximum output power and fill factor decrease by temperature and short circuit current increase by temperature, which affect the efficiency. The different photovoltaic technologies have different temperature coefficients, however, its temperature coefficients are less and it may vary between $0.5 \% /{ }^{\circ} \mathrm{C}$ to $-0.26 \% /{ }^{\circ} \mathrm{C}$. Furthermore, it can have a large effect during warm weather and decrease the performance of the photovoltaic system [6].

Moreover, every location has its characteristics like sunny hours in a day or sunny days in a year, the temperatures during the month and year, and the amount of irradiance which absorbs by earth surface as well as the intensity of the sun's rays. These parameters significantly affect the efficiency of conversion of solar energy to the electricity by photovoltaic cells. Therefore, the location in the design of the photovoltaic system is very important, and it directly affects the efficiency of a photovoltaic system $[15,16]$. It means a location with direct radiation of the sun and a long period of daylight will receive more isolation. Since the more energy or the irradiance of the sun received by the photovoltaic module, the more energy it can produce as electricity. This dependency of the photovoltaic system to location is one of the negative points for photovoltaic systems.

Finally, the angle of solar radiation varies during of year, because the sun is not always at the one position and its location during the year, month and day varies. Generally, in the northern hemisphere, the photovoltaic oriented toward the south side and in the southern hemisphere oriented toward the north side and the incident of solar radiation depends on the tilt angle of the photovoltaic module. The tilt angle of photovoltaic modules is an important parameter in photovoltaic systems, it depends on the location of the sun. And it is very important to choose an appropriate tilt angle or use system to track the sun to harvest maximum power from the photovoltaic system.

\section{Solution mechanisms}

To determine the best possible solution of previously mentioned issue following steps are suggested in this research. First, we will seek to find an appropriate photovoltaic module. It is obvious that if we choose a module with high efficiency is good but they are expensive and are not suitable to use on large scale plants. Also, a high efficiency does not mean to have good performance, there are some other factors that should be attained to have the best photovoltaic system performance and output Such as temperature coefficient, location, and tilt angle. Therefore, selection of modules with appropriate efficiency and temperature coefficient is required in this step.

Second, after choosing the appropriate module with a suitable temperature coefficient, it is time for selection of best location for our photovoltaic system. For the selection of location, we should attain the temperature and the sunny hours of the day. 
Third, we should find an optimum tilt angle for a specific location. However, there is a tracking system available to move the module in its maximum irradiance, but is leads to high capital cost of photovoltaic system which is economically not suitable. Therefore, a fixed tilt angle to obtain maximum energy is highly recommended.

\section{Local data analysis}

Finding out the best possible module, location, and installation tilt angle, a simple method using an estimation tool (PV Watt) is carried out in this research [17]. PV Watt is a tool powered by NREL that estimates the energy production and cost of energy of grid-connected photovoltaic energy systems throughout the world. This allows us to estimate the energy production and performance of the photovoltaic system in a different area. PV Watt is used to estimate these important parameters for Kabul and Kandahar city of Afghanistan.

\subsection{Effect of different module on performance of photovol- taic systems}

To investigate how much the different module affects performance of the photovoltaic system on the specific location, two different locations in two cities with different weather condition are selected. PVwatts is used to estimate the monthly DC output of the proposed $10 \mathrm{~kW}$ photovoltaic system. Three types of photovoltaic modules for our estimation are considered, which have different characteristics. For example, the first module is crystalline silicon with $15 \%$ efficiency and temperature coefficient ($0.47 \% /{ }^{\circ} \mathrm{C}$ ). The second module is crystalline silicon with $19 \%$ efficiency and temperature coefficient $\left(-0.35 \% /{ }^{\circ} \mathrm{C}\right)$. The third module is a thin film with a $10 \%$ efficiency and temperature coefficient $\left(-0.20 \% /{ }^{\circ} \mathrm{C}\right)$. After estimation based on PVwatts, DC output of these three modules are found as shown in Table 1 and Table 2.

Table 1: DC output of different module for Kabul city.

\begin{tabular}{llll}
\hline Month & Module 1 $(\mathrm{kWh})$ & Module 2 $(\mathrm{kWh})$ & Module 3 $(\mathrm{kWh})$ \\
\hline Jan & 1317.86 & 1325.10 & 1331.02 \\
Feb & 1086.02 & 1085.17 & 1081.59 \\
Mar & 1588.87 & 1611.95 & 1633.83 \\
Apr & 1589.83 & 1618.90 & 1648.41 \\
May & 1781.24 & 1833.85 & 1891.81 \\
Jun & 1880.96 & 1944.40 & 2013.64 \\
Jul & 1855.32 & 1925.90 & 2004.07 \\
Aug & 1741.02 & 1812.11 & 1890.37 \\
Sep & 1683.02 & 1752.04 & 1827.28 \\
Oct & 1676.81 & 1731.69 & 1792.06 \\
Nov & 1510.15 & 1533.41 & 1557.99 \\
Dec & 1432.17 & 1443.64 & 1454.80 \\
\hline
\end{tabular}

Table 2: DC output of different module for Kandahar city.

\begin{tabular}{llll}
\hline Month & Module 1 $(\mathrm{kWh})$ & Module 2 $(\mathrm{kWh})$ & Module 3 $(\mathrm{kWh})$ \\
\hline Jan & 1321.40 & 1329.02 & 1334.45
\end{tabular}

\begin{tabular}{llll}
\hline Feb & 1236.63 & 1244.12 & 1249.49 \\
Mar & 1688.54 & 1724.41 & 1761.08 \\
Apr & 1704.54 & 1748.45 & 1794.78 \\
May & 1883.97 & 1949.14 & 2020.77 \\
Jun & 1828.33 & 1912.52 & 2007.28 \\
Jul & 1772.11 & 1866.59 & 1974.81 \\
Aug & 1710.13 & 1788.38 & 1877.18 \\
Sep & 1719.81 & 1790.97 & 1868.66 \\
Oct & 1784.79 & 1842.13 & 1904.75 \\
Nov & 1617.90 & 1656.11 & 1698.43 \\
Dec & 1590.01 & 1605.25 & 1620.46 \\
\hline
\end{tabular}

\subsection{Effect of Temperature on the performance of photovol- taic systems:}

Temperature has a significant effect on the performance of photovoltaic systems. For finding the effect of temperature on the output of the photovoltaic system, we need to find the temperature of the specific location and estimate the performance of photovoltaic systems. For this purpose, we chose Kabul city and Kandahar city with different temperatures which are in different climate conditions and suitable for a wide range of study.

At first, we find the ambient temperature of Kabul city and Kandahar city by using the NREL estimation Tool (PVwatts) and cell temperature of the module on the Kabul city and Kandahar city accordingly. Table 3 and Table 4summarize the monthly ambient temperature and cell temperature of these two cities. Table 3 shows, the maximum average temperature for Kabul city $27^{\circ} \mathrm{C}$ in August, and the cell temperature $43^{\circ} \mathrm{C}$. The maximum average ambient temperature is $33^{\circ} \mathrm{C}$ in July, and the cell temperature is $50^{\circ} \mathrm{C}$ for Kandahar city, as shown in Table 4 .

Table 3: Ambient temperature and cell temperature of Kabul city

\begin{tabular}{lll}
\hline Month & Ambient temperature $\left({ }^{\circ} \mathrm{C}\right)$ & Cell temperature $\left({ }^{\circ} \mathrm{C}\right)$ \\
\hline Jan & 2.57 & 17.58 \\
Feb & 2.70 & 14.67 \\
Mar & 10.34 & 24.45 \\
Apr & 12.90 & 27.89 \\
May & 21.32 & 35.65 \\
Jun & 25.45 & 40.13 \\
Jul & 26.99 & 41.92 \\
Aug & 27.25 & 42.59 \\
Sep & 23.94 & 43.51 \\
Oct & 19.11 & 38.82 \\
Nov & 8.47 & 26.94 \\
Dec & 3.43 & 21.20 \\
\hline
\end{tabular}

Table 4: Ambient temperature and cell temperature of Kandahar city.

\begin{tabular}{lll}
\hline Month & Ambient temperature $\left({ }^{\circ} \mathrm{C}\right)$ & Cell temperature $\left({ }^{\circ} \mathrm{C}\right)$ \\
\hline Jan & 6.05 & 18.47 \\
Feb & 8.49 & 19.79 \\
Mar & 15.39 & 30.51 \\
Apr & 20.64 & 35.16
\end{tabular}




\begin{tabular}{lll} 
May & 26.22 & 39.82 \\
Jun & 31.50 & 47.24 \\
Jul & 33.27 & 50.44 \\
Aug & 31.16 & 47.15 \\
Sep & 27.26 & 44.69 \\
Oct & 19.93 & 39.02 \\
Nov & 15.34 & 34.81 \\
Dec & 7.27 & 24.01 \\
\hline
\end{tabular}

\subsection{Effect of location on performance of photovoltaic sys- tems}

In this part, we will investigate the effect of a different location on the performance of photovoltaic systems. It is previously discussed that two locations with different weather conditions, and different insolation are selected. These locations have different solar irradiance, and obviously, the different modules with different characters have a specific performance on each location.

The Kabul city and Kandahar city, which we chose for our investigation have $34.55^{\circ} \mathrm{N}$ latitude and $69.15^{\circ} \mathrm{E}$ longitude and $31.65^{\circ} \mathrm{N}$ latitude and $67.05^{\circ} \mathrm{E}$ longitude, respectively. Table 5 , Table 6 , and Table 7 show the DC output of three modules with different characteristics.

Table 5: Module 1 DC output of Kabul and Kandahar cities.

\begin{tabular}{lll}
\hline Month & Kabul $(\mathrm{kWh})$ & Kandahar $(\mathrm{kWh})$ \\
\hline Jan & 1317.86 & 1321.40 \\
Feb & 1086.02 & 1236.63 \\
Mar & 1588.87 & 1688.54 \\
Apr & 1589.83 & 1704.54 \\
May & 1781.24 & 1883.97 \\
Jun & 1880.96 & 1828.33 \\
Jul & 1855.32 & 1772.11 \\
Aug & 1741.02 & 1710.13 \\
Sep & 1683.02 & 1719.81 \\
Oct & 1676.81 & 1784.79 \\
Nov & 1510.15 & 1617.90 \\
Dec & 1432.17 & 1590.01 \\
\hline
\end{tabular}

Table 6: Module 2 DC output of Kabul and Kandahar cities.

\begin{tabular}{lll}
\hline \hline Month & Kabul $(\mathrm{kWh})$ & Kandahar $(\mathrm{kWh})$ \\
\hline Jan & 1325.10 & 1329.02 \\
Feb & 1085.17 & 1244.12 \\
Mar & 1611.95 & 1724.41 \\
Apr & 1618.90 & 1748.45 \\
May & 1833.85 & 1949.14 \\
Jun & 1944.40 & 1912.52 \\
Jul & 1925.90 & 1866.59 \\
Aug & 1812.11 & 1788.38 \\
Sep & 1752.04 & 1790.97 \\
Oct & 1731.69 & 1842.13 \\
Nov & 1533.41 & 1656.11 \\
Dec & 1443.64 & 1605.25 \\
\hline \hline
\end{tabular}

Table 7: Module 3 DC output of Kabul and Kandahar cities.

\begin{tabular}{lll}
\hline Month & Kabul $(\mathrm{kWh})$ & Kandahar $(\mathrm{kWh})$ \\
\hline Jan & 1331.02 & 1334.45 \\
Feb & 1081.59 & 1249.49 \\
Mar & 1633.83 & 1761.08 \\
Apr & 1648.41 & 1794.78 \\
May & 1891.81 & 2020.77 \\
Jun & 2013.64 & 2007.28 \\
Jul & 2004.07 & 1974.81 \\
Aug & 1890.37 & 1877.18 \\
Sep & 1827.28 & 1868.66 \\
Oct & 1792.06 & 1904.75 \\
Nov & 1557.99 & 1698.43 \\
Dec & 1454.80 & 1620.46 \\
\hline \hline
\end{tabular}

\subsection{The optimal tilt angle of photovoltaic module}

The optimal tilt angle as has been discussed in [12] which varies from month to month is evaluated based on PVwatts. In this section, optimal monthly, seasonal, and yearly tilt angle of the photovoltaic module is found which is demonstrated Table 8,9 , and 10 , respectively.

Table 8: Monthly optimal tilt angle.

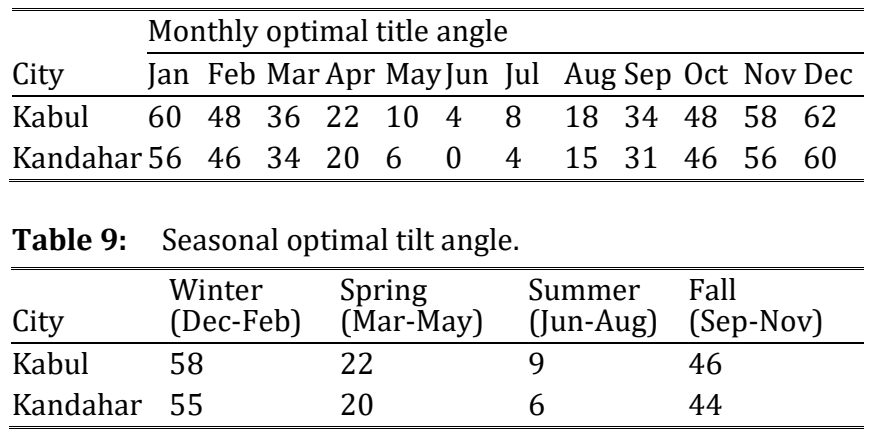

Table 10: Annually optimal tilt angle.

\begin{tabular}{ll}
\hline \hline City & Yearly optimal title angle \\
\hline Kabul & 33 \\
Kandahar & 31 \\
\hline
\end{tabular}

The DC output of proposed $10 \mathrm{~kW}$ system is analyzed for Kabul city and comparatively calculated in each level of tilt angle consideration as shown in Table 1.

Table 11: Performance of photovoltaic module at optimal tilt angle in Kabul city

\begin{tabular}{llll}
\hline & $\begin{array}{l}\text { Optimal tilt angle } \\
\text { (monthly) } \\
\text { (kWh) }\end{array}$ & $\begin{array}{l}\text { Optimal tilt angle Optimal tilt angle } \\
\text { (seasonal) } \\
\text { (kWh) }\end{array}$ & $\begin{array}{l}\text { (annual) } \\
\text { (kWh) }\end{array}$ \\
\hline Jan & 1317.86 & 1317.96 & 1212.64 \\
Feb & 1086.02 & 1073.72 & 1059.35 \\
Mar & 1588.87 & 1547.66 & 1586.13 \\
Apr & 1589.83 & 1589.83 & 1568.85 \\
May & 1781.24 & 1752.43 & 1678.30 \\
Jun & 1880.96 & 1874.36 & 1698.42 \\
Jul & 1855.32 & 1854.64 & 1712.81 \\
Aug & 1741.02 & 1726.81 & 1692.25 \\
Sep & 1683.02 & 1675.76 & 1682.98
\end{tabular}




\begin{tabular}{llll} 
Oct & 1676.81 & 1482.48 & 1629.19 \\
Nov & 1510.15 & 1385.39 & 1392.27 \\
Dec & 1432.17 & 1428.88 & 1281.18 \\
\hline
\end{tabular}

\section{Result and discussion}

\subsection{Effect of different modules on performance of photovol- taic systems}

For having the better realization of different modules and how it performs on the different locations and climate conditions, figure 1 to 4 illustrate the performance of each module for Kabul and Kandahar, respectively. These graphs reveal that how different modules perform, and clarify that the thin film with $10 \%$ efficiency and temperature coefficient $\left(-0.20 \% /{ }^{\circ} \mathrm{C}\right)$, has the best performance for Kabul and Kandahar city. The second-best performance is discovered from module 2 which is crystalline silicon and has $19 \%$ efficiency and with temperature coefficient $\left(-0.35 \% /{ }^{\circ} \mathrm{C}\right)$. Module 1 as crystalline silicon with $15 \%$ efficiency and temperature coefficient $\left(-0.47 \% /{ }^{\circ} \mathrm{C}\right)$, has less performance than the module 2 and module 3 .

The estimation of the energy output of $10 \mathrm{~kW}$ reveals that for Kabul, module 1 generates 19,143.34 kWh, module 2 generates 19,618.2 $\mathrm{kWh}$, and module 3 generates 20,126.93 kWh annually. For Kandahar city, module 1generates 19,858.22 kWh, module 2 generates 20,457.16 $\mathrm{kWh}$, and module 3 generates 21,112.21 kWh annually. Figure 2 and 4 show the annual energy generation of Kabul and Kandahar city, respectively. Finally, Module 3 (thin film with $10 \%$ efficiency and temperature coefficient $\left.\left(-0.20 \% /{ }^{\circ} \mathrm{C}\right)\right)$ is found to be with best results for Kabul and Kandahar. Using thin-film module for $10 \mathrm{~kW}$ photovoltaic system in Kabul city, we achieve 508.73 kWh more energy annually than using crystalline silicon with $19 \%$ efficiency with temperature coefficient $\left(-0.35 \% /{ }^{\circ} \mathrm{C}\right)$. Moreover, it can be achieved $983.59 \mathrm{kWh}$ more energy annually than using crystalline silicon with $15 \%$ efficiency with temperature coefficient $\left(-0.47 \% /{ }^{\circ} \mathrm{C}\right)$.

In Kandahar city, If we use a thin film module for $10 \mathrm{~kW}$ photovoltaic system we can achieve $655.05 \mathrm{kWh}$ more energy annually than using crystalline silicon with $19 \%$ efficiency with temperature coefficient $\left(-0.35 \% /{ }^{\circ} \mathrm{C}\right)$. Also, we can achieve $1253.99 \mathrm{kWh}$ more energy annually than using crystalline silicon with $15 \%$ efficiency with temperature coefficient $\left(-0.47 \% /{ }^{\circ} \mathrm{C}\right)$.

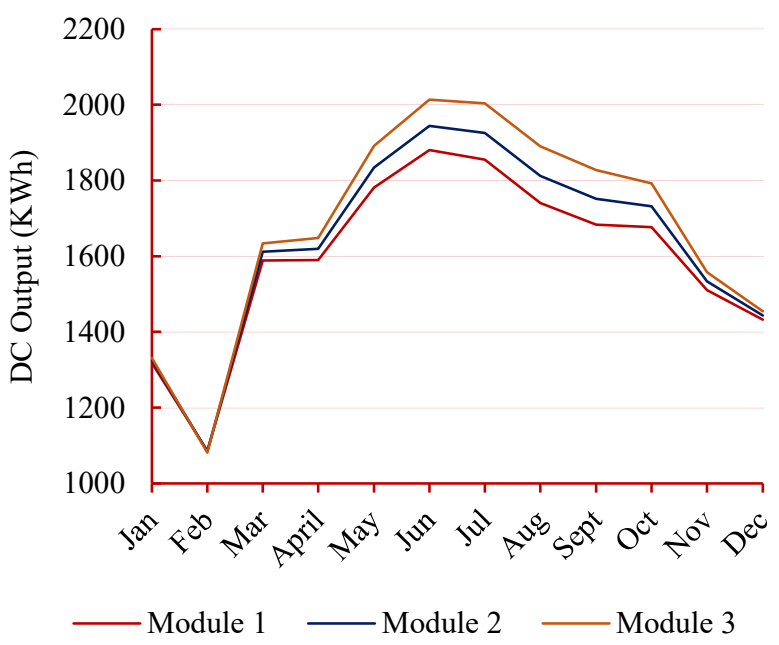

Figure 1. Graphs of DC output of different module for the Kabul city.

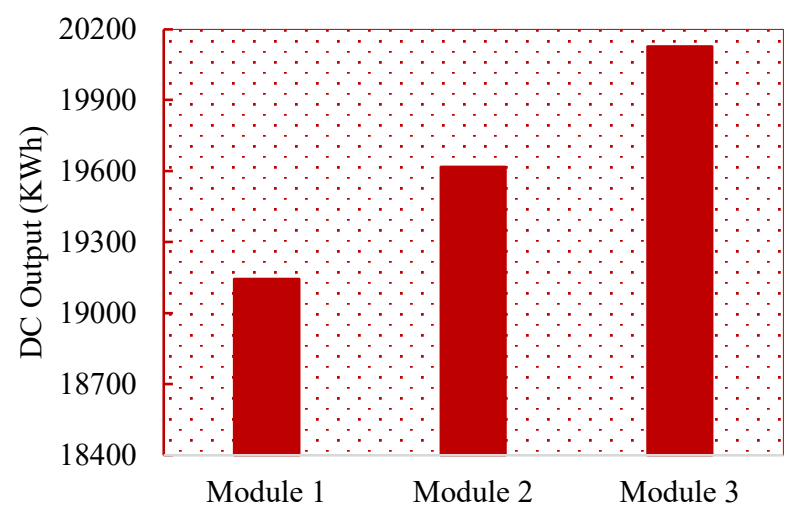

Figure 2. Annual DC output estimation of different modules for Kabul city.

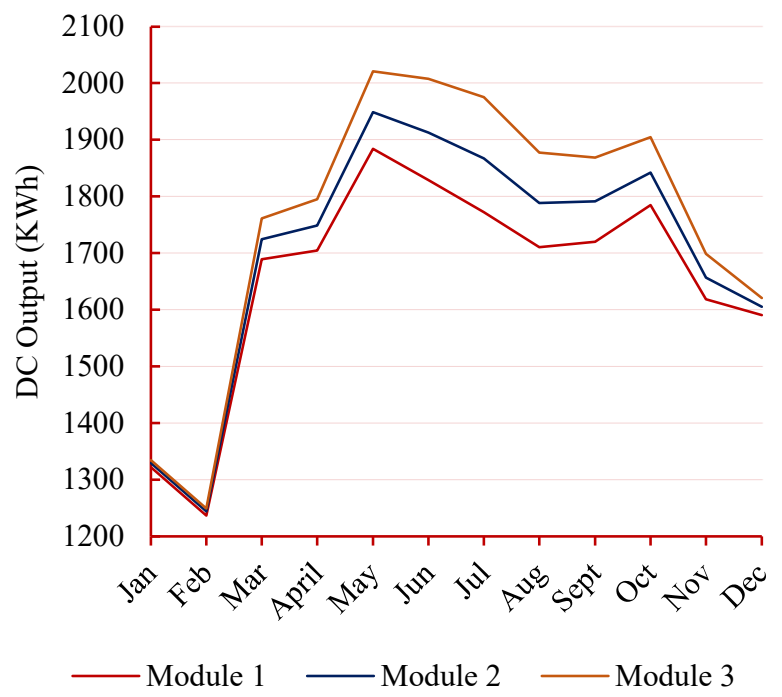

Figure 3. Graph of DC output of different module for Kandahar city. 


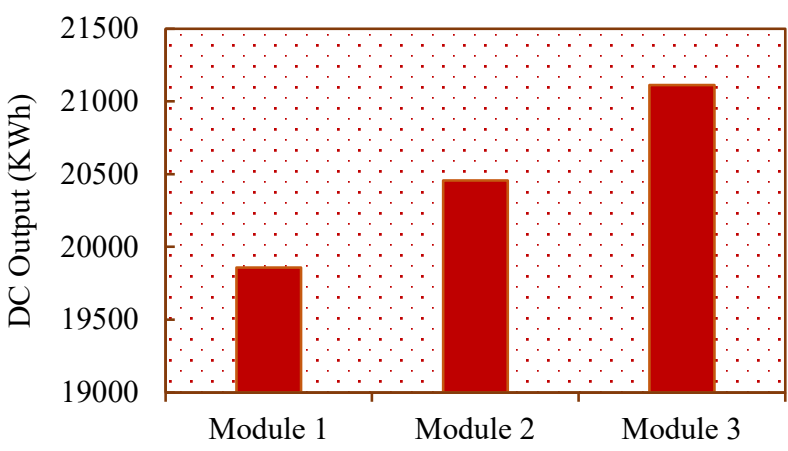

Figure 4. Annual DC output estimation of different modules for Kandahar city.

\subsection{Effect of temperature on the performance of photovol- taic systems:}

The cell temperature not only changes with ambient temperatures but also change with insolation on the cells. The small part of the insolation is converted to the electricity by photovoltaic cell and the other part of insolation absorbs and changes to heat. This causes to having cell temperature more than the ambient temperature $[18,19]$. Figure 4 shows the monthly variation of cell temperature for Kabul and Kandahar city. We realize that the cell temperature on the Kandahar varies widely from Kabul city during the year.

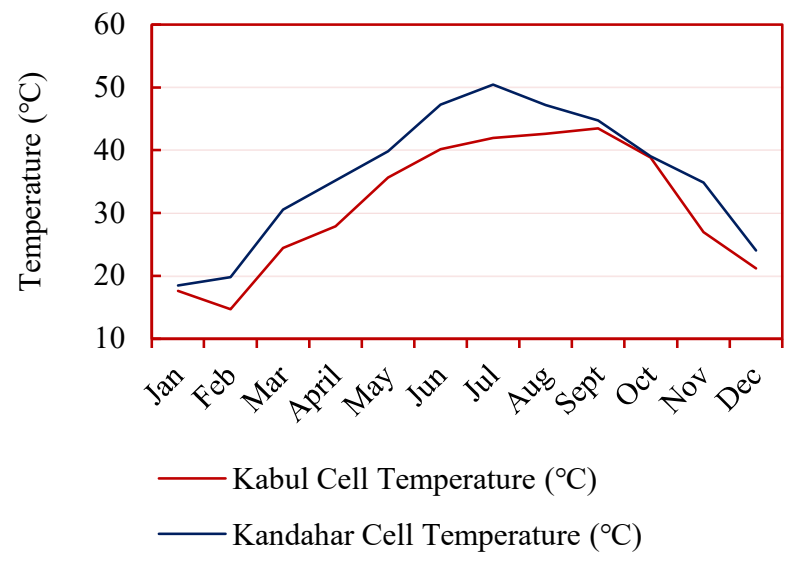

Figure 5. Cell temperature of Kabul and Kandahar city.

From this investigation, We found that how much power the $10 \mathrm{~kW}$ photovoltaic system generates when using different modules with different temperature coefficients as well as having different temperature conditions. For example, in Kabul city, the thin-film module with 10\% efficiency and $\left(-0.20 \% /{ }^{\circ} \mathrm{C}\right)$, generates $4.8 \%, 2.5 \%$ more energy than the crystalline silicon modules with $15 \%$ efficiency and $\left(-0.47 \% /{ }^{\circ} \mathrm{C}\right)$ temperature coefficient and $19 \%$ efficiency and $\left(-0.35 \% /{ }^{\circ} \mathrm{C}\right)$ temperature coefficient. For Kandahar city, the thin-film module with $10 \%$ efficiency and $\left(-0.20 \% /{ }^{\circ} \mathrm{C}\right)$, generates $6 \%, 3.1 \%$ more energy than the crystalline silicon modules with $15 \%$ efficiency and ($0.47 \% /{ }^{\circ} \mathrm{C}$ ) temperature coefficient and $19 \%$ efficiency and $\left(-0.35 \% /{ }^{\circ} \mathrm{C}\right)$ temperature coefficient. In result, the temperature has a significant effect on the performance of the photovoltaic system which a module with $10 \%$ efficiency and low-temperature coefficient has better performance than the modules with $15 \%$ and $19 \%$ efficiency with temperature coefficient $\left(-0.47 \% /{ }^{\circ} \mathrm{C}\right)$ and $(-$ $0.35 \% /{ }^{\circ} \mathrm{C}$ ).

\subsection{Effect of location on performance of photovoltaic sys- tems:}

The output of three modules in Kabul and Kandahar reveal that the module with large temperature coefficient (module 1 with $-0.47 \% /{ }^{\circ} \mathrm{C}$ temperature coefficient) in hot weather at Kandahar city has less performance than for Kabul city and the performance of module with less temperature coefficient (module 3 with $-0.20 \% /{ }^{\circ} \mathrm{C}$ temperature coefficient) on the hot month of Kandahar city has less variation compare to Kabul city.

\subsection{Proposed tilt angle of photovoltaic module:}

Finally, the effect of tilt angle on the output performance of photovoltaic systems is found accordingly. By changing the tilt angle monthly for Kabul city, 433.38 kWh more energy is achievable than the seasonal and annual changing options. Also, we can achieve $948.91 \mathrm{kWh}$ more energy than the fixed tilt angle during the year (see fig.8).

For Kandahar city also monthly changing of tilt angle results on $338.12 \mathrm{kWh}$ more energy than the seasonal changing during a year. $1033.77 \mathrm{kWh}$ more energy is achievable than the fixed tilt angle during the year as well (figure 9).

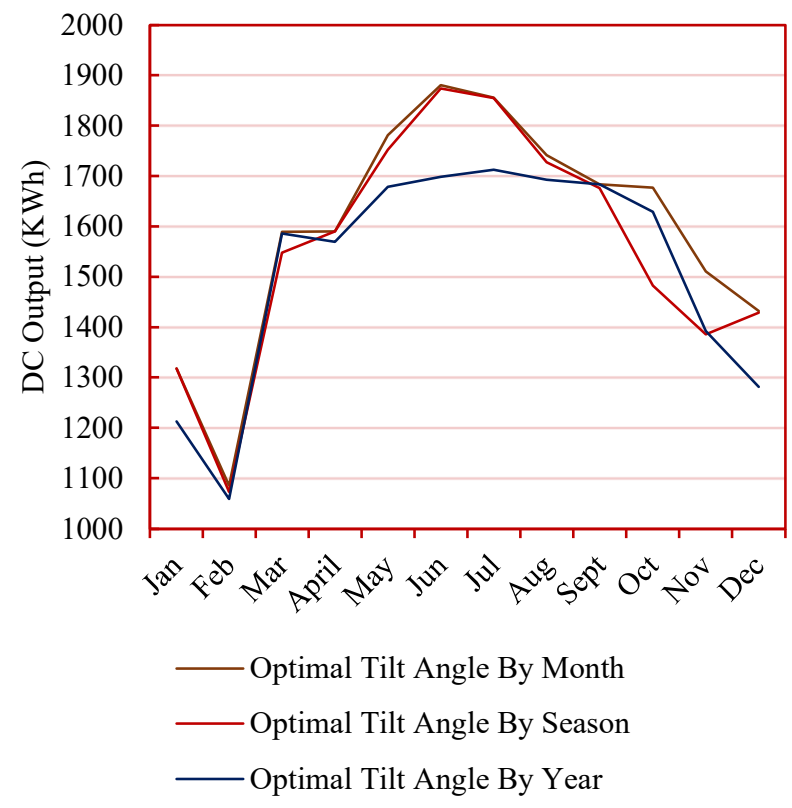

Figure 6. Graph of DC output of optimal tilt angle of Kabul city. 


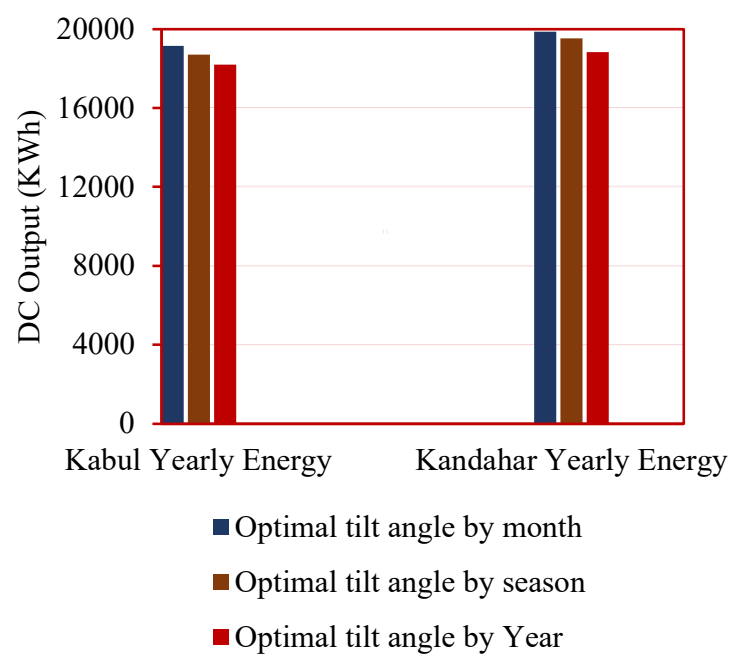

Figure 7. Optimal tilt angle.

\section{Cost analysis}

A cost analysis is considered to demonstrate saving from the implementation of proposed approach. Three modules, two locations, different optimal tilt angles, and a $10 \mathrm{~kW}$ photovoltaic system are utilized for this analysis. First, we find that how much we can save money by using the best module, as we found previously. The best module with the best performance for Kabul and Kandahar city is thin film with $10 \%$ efficiency and $\left(-0.20 \% /{ }^{\circ} \mathrm{C}\right)$ temperature coefficient. The thin-film module has the lowest cost as well as the best performance among these three modules.

By investigating the cost of energy-saving, using the residential electricity price of DABs $(0.038 \%$ per $\mathrm{kWh})$ for Kabul city, it reveals that thin-film module saves $19.33 \$$ more money annually than using crystalline silicon with $19 \%$ efficiency, and we can save $37.37 \$$ more money annually than using crystalline silicon with $15 \%$ efficiency. For the case of Kandahar city, it reveals that using thin-film can save $24.89 \$$ more money annually than using crystalline silicon with $19 \%$ efficiency, and we can save $47.65 \$$ more money annually than using crystalline silicon with $15 \%$ efficiency.

For Kabul city, if we change the tilt angle monthly, we can save $16.46 \$$ more money than the seasonal changing of tilt angle or change the tilt angle of the module four times annually. Also, we can save $36.05 \$$ more money than the fixed tilt angle during the year. For Kandahar city, if we change the tilt angle monthly, we can save $12.84 \$$ more money than the seasonal changing of tilt angle. Also, we can save $39.28 \$$ more than the fixed tilt angle during the year.

\section{Conclusion}

In Conclusion, the modules with low and high-temperature coefficients have a significant effect on the performance of photovoltaic systems. As it was found that the module with $10 \%$ efficiency and with a low-temperature coefficient has better performance than the module with the $15 \%$ and $19 \%$ efficiency with a high-temperature coefficient. Moreover, the location as another important factor also is found as a significant effect on the performance of the photovoltaic system. For example, the Kandahar city generates $715 \mathrm{kWh}, 839 \mathrm{kWh}$, and $985 \mathrm{kWh}$ more energy annually than the Kabul city by modules 1, 2, and 3, respectively. Finally, for Kabul city, changing the tilt angle monthly, provides $433 \mathrm{kWh}$ and $949 \mathrm{kWh}$ more energy than the changing tilt angle seasonal and annually. For Kandahar city, if we change the tilt angle monthly, it generates $338 \mathrm{kWh}$ and $1034 \mathrm{kWh}$ more energy than the changing tilt angle seasonal and annually. This study besides preliminary calculations contributes to future consideration of photovoltaic in Afghanistan as well as providing background knowledge on factors affecting such systems. The future extended version of this study will focus on comparing several methods and algorithms in the literature to apply in different models as well as completing the analysis for rest of the cities in Afghanistan.

\section{References}

[1] Danish MSS, Yona A, Senjyu T (2014) "Pre-design and life cycle cost analysis of a hybrid power system for rural and remote communities in Afghanistan" The Journal of Engineering-IET (vol. 2014, no. 8, pp. 438-444) https://doi.org/10.1049/joe.2014.0172

[2] Danish MSS, Sabory NR, Danish SMS, Ludin GA, Yona A, et al. (2016) "An Open-door Immature Policy for Rural Electrification: A Case Study of Afghanistan" International Journal of Sustainable and Green Energy (vol. 6, no. 3, pp. 8-13) https://doi.org/10.11648/j.ijrse.s.2017060301.12

[3] Yaqobi MA, Matayoshi H, Danish MSS, Urakaki N, Howlader AM, et al. (2018) "Control and Energy Management Strategy of Standalone DC Microgrid Cluster using PV and Battery Storage for Rural Application" International Journal of Power and Energy Research (vol. 2, no. 4, pp. 53-68) https://doi.org/10.22606/ijper.2018.24001

[4] Susowake Y, Ibrahimi AM, Danish MSS, Senjyu T, Howlader AM, et al. (2018) "Multi-Objective Design of Power System Introducing Seawater Electrolysis Plant for Remote Island" IEEE Innovative Smart Grid Technologies - Asia (ISGT Asia) Singapore, Singapore, IEEE - pp. 908-911. https://doi.org/10.1109/ISGT-Asia.2018.8467912 (https://ieeexplore.ieee.org/document/8467912) 
[5] Tobaru S, Muarapaz CC, Conteh F, Senjyu T, Howlader AM, et al. (2016) "Design of hybrid renewable energy systems considering optimal real-time pricing" 2016 IEEE Region 10 Conference (TENCON) Singapore, Singapore, IEEE - pp. 3206-3209. https://doi.org/10.1109/TENCON.2016.7848 641 (https://ieeexplore.ieee.org/document/7848641)

[6] Ahmadi M, Lotfy ME, Howlader AM, Yona A, Senjyu T (2019) "Centralised multi-objective integration of wind farm and battery energy storage system in real-distribution network considering environmental, technical and economic perspective" Transmission Distribution IET Generation (vol. 13, no. 22, pp. 5207-5217) https://doi.org/10.1049/iet-gtd.2018.6749

[7] Danish MSS, Matayoshi H, Howlader HOR, Chakraborty S, Mandal P, et al. (2019) "Microgrid Planning and Design: Resilience to Sustainability" 2019 IEEE PES GTD Grand International Conference and Exposition Asia (GTD Asia) Bangkok, Thailand, IEEE - pp. 253-258. https://doi.org/ 10.1109/GTDAsia.2019.8716010

[8] Danish MSS, Sabory NR, Ershad AM, Danish SMS, Yona A, et al. (2017) "Sustainable Architecture and Urban Planning trough Exploitation of Renewable Energy" International Journal of Sustainable and Green Energy (vol. 6, no. 3, pp. 17) https://doi.org/10.11648/j.ijrse.s.2017060301.11

[9] Ahmadi M, Lotfy ME, Danish MSS, Ryuto S, Yona A, et al. (2019) "Optimal multi-configuration and allocation of SVR, capacitor, centralised wind farm, and energy storage system: a multi-objective approach in a real distribution network" IET Renewable Power Generation (vol. 13, no. 5, pp. 762-773) https://doi.org/10.1049/iet-rpg.2018.5057

[10] Ahmadi M, Lotfy ME, Shigenobu R, Yona A, Senjyu T (2018) "Optimal sizing and placement of rooftop solar photovoltaic at Kabul city real distribution network" Transmission Distribution IET Generation (vol. 12, no. 2, pp. 303-309) https://doi.org/10.1049/iet-gtd.2017.0687
[11] Chikate BV, Sadawarte Y (2015) "The factors affecting the performance of solar cell" International journal of computer applications (vol. 1, no. 1, pp. 0975-8887)

[12] Jain D, Lalwani M (2017) “A Review on Optimal Inclination Angles for Solar Arrays" International Journal of Renewable Energy Research (IJRER) (vol. 7, no. 3, pp. 1053-1061)

[13] Deb SK (2000) "Chapter 584 - Recent Developments in High-Efficiency PV Cells" In: Sayigh AAM - editor. World Renewable Energy Congress VI Oxford, Pergamon - pp. 2658$2663 . \quad$ https://doi.org/10.1016/B978-0080438658/50584-5

[14] Nair KK, Jose J, Ravindran A (2016) "Analysis of temperature dependent parameters on solar cell efficiency using MATLAB" (vol. 4, no. 3, pp. 6)

[15] Jäger K-D, Isabella O, Smets AHM, Swaaij RACMM van, Zeman M (2016) "Solar energy: fundamentals, technology and systems" p. ISBN: 978-1-906860-73-8

[16] Masters GM (2004) "Renewable and Efficient Electric Power Systems," 2nd ed. USA, Wiley. 647 p. ISBN: 0-47128060-7 (http://www.a-ghadimi.com/files/Courses/Renewable\%20Energy/REN_Book.pdf)

[17] PVWATTS free solar calculator (2019) Photovoltaic Software (https://photovoltaic-software.com/pv-softwarescalculators/online-free-photovoltaic-software/pvwattsnrel) Accessed: 9 April 2020

[18] Dash PK, Gupta NC (2015) "Effect of temperature on power output from different commercially available photovoltaic modules" International Journal of Engineering Research and Applications (vol. 5, no. 1, pp. 148-151)

[19] Singh P, Ravindra NM (2012) "Temperature dependence of solar cell performance: An analysis" Solar Energy Materials and Solar Cells (vol. 101, pp. 36-45) https://doi.org/10.1016/j.solmat.2012.02.019 